\title{
DETERMINASI PROFITABILITAS PERUSAHAAN MANUFAKTUR YANG TERDAFTAR DI BURSA EFEK INDONESIA TAHUN 2015-2019
}

\author{
Martini \\ Akuntansi, Fakultas Ekonomi dan Bisnis, Universitas Budi Luhur \\ Jl. Ciledug raya Petukangan Utara, Jakarta, 12260 \\ E-mail : martini@budiluhur.ac.id ${ }^{1)}$
}

\begin{abstract}
ABSTRAK
Profitabilitas dapat menggambarkan kemampuan sebuah perusahaan dalam menghasilkan laba (keuntungan) selama suatu periode tertentu. Profitabilitas suatu perusahaan dapat mempengaruhi kebijakan para investor atas investasi yang ditanamkan pada sebuah perusahaan. Kemampuan perusahaan dalam menghasilkan laba ini dapat menarik minat para investor untuk menanamkan dananya guna memperluas usahanya, begitu juga sebaliknya. Jika tingkat profitabilitas perusahaan rendah akan dapat menyebabkan para investor menarik dananya dari perusahaan. Penelitian ini bertujuan untuk mengetahui pengaruh debt to equity ratio, current ratio, firm size, dan pertumbuhan penjualan terhadap profitabilitas. Penelitian ini dilakukan pada Perusahaan Manufaktur Sub Sektor Peralatan Rumah Tangga, kosmetik \& Keperluan Rumah Tangga dan Rokok yang Terdaftar di Bursa Efek Indonesia Tahun 2015-2019 sebanyak 16 perusahaan. Sampel penelitian ini dipilih melalui teknik purposive random sampling. Metode analisis yang digunakan adalah analisis regresi berganda. Hasil penelitian ini menunjukkan bahwa debt to equity ratio, current ratio, dan firm size berpengaruh positif dan signifikan terhadap profitabilitas, sedangkan pertumbuhan penjualan tidak berpengaruh terhadap profitabilitas. Nilai profitabilitas yang diperiksakan dengan Return On Assets ditentukan oleh variabel Debt to Equity Ratio, Current Ratio, Firm Size dan Pertumbuhan Penjualan sebesar 45.7\%, sisanya dijelaskan oleh variabel-variabel lain diluar penelitian seperti Total Assets Turn Over, Assets Tangibility, Debt to Total Assets, Inventory Turnover.
\end{abstract}

Kata Kunci: Debt To Equity Ratio, Current Ratio, Firm Size, Pertumbuhan Penjualan, Profitabilitas

\section{PENDAHULUAN}

Tim riset CNBC Indonesia (cnbcindonesia.com, 2019) menemukan terdapat 3 perusahaan yang mengalami kerugian selama 8 tahun yaitu PT Krakatau Steel Tbk (KRAS), PT Smartfren Telecom Tbk (FREN) dan PT Bentoel Internasional Investama Tbk (RMBA). Dua dari tiga perusahaan tersebut adalah milik swasta, yaitu PT Smartfren Telecom Tbk (FREN) dan PT Bentoel Internasional Investama Tbk (RMBA). Ketiga emiten tersebut, setidaknya sejak 2012 tak pernah absen merugi, bahkan nilainya membengkak dari tahun ke tahun.

Profitabilitas menggambarkan kemampuan perusahaan dalam menghasilkan laba (keuntungan) dalam suatu periode tertentu. Profitabilitas suatu perusahaan dapat mempengaruhi kebijakan para investor atas investasi yang ditanamkan pada sebuah perusahaan. Kemampuan perusahaan dalam menghasilkan laba dapat menarik para investor untuk menanamkan dananya guna memperluas usahanya, begitu juga sebaliknya. Jika tingkat profitabilitas perusahaan rendah dapat menyebabkan para investor menarik dananya dari perusahaan. Banyak faktor yang mampu mempengaruhi profitabilitas perusahaan. Faktor-faktor itu diantaranya adalah Debt to Equity Ratio (DER), Current Ratio (CR), Firm Size dan Pertumbuhan Penjualan.

DER diprediksi mempunyai hubungan positif dengan profitabilitas oleh trade off theory. Trade off theory merupakan teori struktur modal yang menjelaskan keseimbangan antara manfaat dan pengorbanan yang ditimbulkan akibat penggunaan utang. Pengurangan bunga utang pada perhitungan penghasilan kena pajak memperkecil proporsi beban pajak sehingga laba bersih setelah pajak menjadi semakin besar, atau tingkat profitabilitas semakin tinggi. DER berpengaruh signifikan terhadap profitabilitas (Efendi, Putri and Dungga, 2019). Sedangkan bahwa DER tidak berpengaruh terhadap profitabilitas penelitian (Angelina et al., 2020).

Dengan nilai current ratio yang rendah, maka kelangsungan kontinuitas operasi perusahaan tidak akan terganggu, dan pendapatan yang diperoleh menjadi meningkat dan laba yang diperoleh tetap besar. Tetapi dengan nilai current ratio yang terlampau tinggi menandakan besarnya Dana menganggur yang tidak digunakan secara optimal bagi kepentingan bisnis sehingga dapat menurunkan profitabilitas. Peneliti (Sari and Dwirandra, 2019) membuktikan bahwa current ratio berpengaruh negatif pada profitabilitas. Sedangkan penelitian (Supardi, H. Suratno and Suyanto, 2018) dan (Warrad, 2015) menemukan bahwa current ratio tidak berpengaruh terhadap profitabilitas.

Semakin besar firm size maka semakin besar jumlah kekayaan perusahaan yang dapat digunakan untuk menunjang kegiatan operasionalnya. Apabila kegiatan operasional perusahaan berjalan dengan lebih baik maka 
produk yang dihasilkan akan lebih banyak sehingga mampu menghasilkan penjualan tinggi dan profitabilitas yang lebih tinggi pula. Penelitian (Wikardi and Wiyani, 2017) dan (Isik, 2017) menemukan bahwa firm size berpengaruh signifikan terhadap profitabilitas. Sedangkan penelitian (Nursatyani, 2014) membuktikan bahwa firm size tidak berpengaruh terhadap profitabilitas.

Tingkat pertumbuhan penjualan yang tinggi menandakan kemampuan perusahaan menghasilkan pendapatan yang tinggi dari penjualan produk perusahaan, sebaliknya jika pertumbuhan rendah menandakan kemampuan perusahaan menghasilkan pendapatan yang rendah dari periode sebelumnya. Semakin tinggi tingkat pertumbuhan penjualan maka semakin tinggi pula profitabilitas perusahaan. Penelitian yang dilakukan oleh (Setyawan and Susilowaty, 2018) Menemukan bahwa pertumbuhan penjualan berpengaruh terhadap profitabilitas. Sedangkan (Mappanyuki and Sari, 2017) membuktikan bahwa pertumbuhan penjualan tidak berpengaruh terhadap profitabilitas.

Berdasarkan uraian di atas, faktor-faktor yang mempengaruhi motivasi dilakukan penelitian ini adalah masih terdapat perbedaan hasil dari penelitian yang pernah ada. Oleh karena itu, peneliti melakukan penelitian tentang "Determinasi Profitabilitas Perusahaan Manufaktur Yang Terdaftar Di Bursa Efek Indonesia Tahun 2015-2019".

\section{RUANG LINGKUP}

Pada penelitian ini dibuat batasan-batasan masalah yang akan dibahas, sebagai berikut (1) Debt to Equity Ratio (DER), Current Ratio (CR), Firm Size dan Pertumbuhan Penjualan, sedangkan variabel dependen nya adalah Profitabilitas, (2) Populasi dalam penelitian ini adalah Perusahaan Manufaktur Sub Sektor Peralatan Rumah Tangga, kosmetik \& Keperluan Rumah Tangga dan Rokok yang terdaftar di Bursa Efek Indonesia Tahun 2015-2019.

Dari batasan masalah di atas dirumuskan bahwa permasalahan yang akan diselesaikan pada penelitian ini adalah apakah Debt to Equity Ratio, Current Ratio, Firm Size dan Pertumbuhan Penjualan berpengaruh terhadap Profitabilitas Perusahaan Manufaktur Sub Sektor Peralatan Rumah Tangga, kosmetik \& Keperluan Rumah Tangga dan Rokok yang Terdaftar di Bursa Efek Indonesia Tahun 2015-2019.

Profitabilitas menunjukkan kemampuan suatu perusahaan dalam menghasilkan laba selama periode tertentu pada tingkat penjualan, aset, dan modal saham tertentu (Nursatyani, 2014) (1).

$$
\text { Return On Asset }=\frac{\text { Net Income }}{\text { Total Assets }}
$$

Debt to Equity Ratio (DER) merupakan rasio yang membandingkan jumlah Hutang terhadap ekuitas. Semakin tinggi angka DER maka diasumsikan perusahaan memiliki resiko yang semakin tinggi terhadap likuiditas perusahaannya. Formula untuk menghitung Debt to Equity ratio. (DER) (Maulita and Tania, 2018) (2).

Debt to Equity Ratio $=\frac{\text { Total Utang }}{\text { Total Modal }}$

Current Ratio mengukur kemampuan perusahaan memenuhi hutang jangka pendeknya dengan menggunakan aktiva lancar yang dimiliki. (Nursatyani, dkk; 2014). Rumus untuk menghitung Current Ratio (Sari and Dwirandra, 2019) (3).

$$
\text { Current Ratio }=\frac{\text { Total Aktiva Lancar }}{\text { Total Utang Lancar }}
$$

Firm size atau Ukuran perusahaan menggambarkan besar kecilnya suatu perusahaan yang dapat dinyatakan dengan total aset yang dimilki oleh perusahaan. Total aset dijadikan sebagai indikator ukuran perusahaan karena sifatnya jangka panjang dibandingkan dengan penjualan. Mengacu kepada penelitian yang dilakukan (Nurfadilah et al., 2015) tentang ukuran perusahaan yang diukur dengan Ln Total Asett (Nurfadilah et al., 2015),

Pertumbuhan penjualan merupakan rasio yang dapat digunakan untuk menggambarkan kenaikan penjualan perusahaan tahun ini dibandingkan dengan penjualan tahun lalu. Semakin tinggi rasio pertumbuhan penjualan maka semakin baik. Adapun rumus pertumbuhan penjualan (Wikardi and Wiyani, 2017) (4).

Pertumbuhan Penjualan $=$

Penjualan Tahun ini- Penjualan Tahun Lalu Penjualan Tahun Lalu

Kerangka pemikiran dapat dilihat pada gambar 1 .

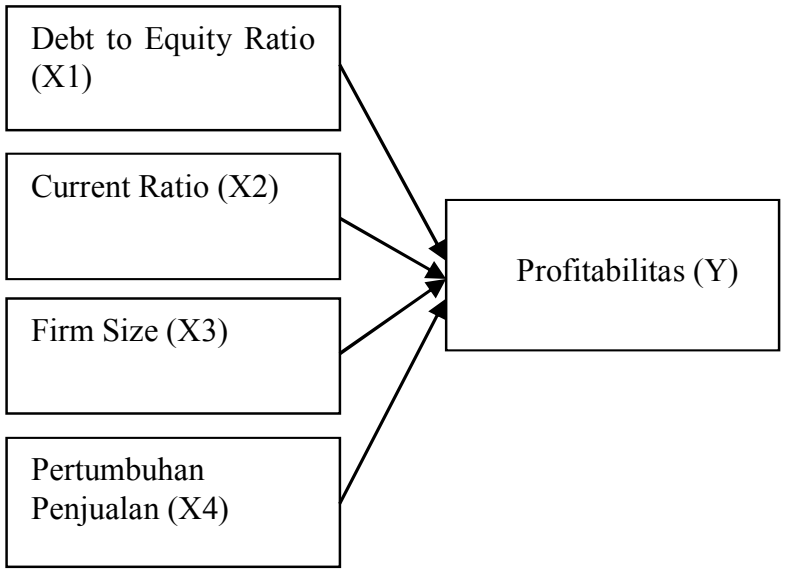

Gambar 1. Kerangka Pemikiran

\section{BAHAN DAN METODE}

Debt to Equity Ratio menunjukkan besarnya hutang yang digunakan untuk membiayai aktiva yang digunakan 
oleh perusahaan dalam rangka menjalankan aktivitas operasionalnya. Dalam Trade off Theory, penggunaan hutang akan meningkatkan nilai perusahaan namun hanya sampai titik tertentu. Semakin besar debt to equity ratio menunjukkan semakin besar tingkat ketergantungan perusahaan terhadap pihak eksternal (kreditur) dan semakin besar pula beban biaya hutang (biaya bunga) yang harus dibayar oleh perusahaan. Semakin tinggi debt to equity ratio berarti semakin kecil jumlah modal pemilik yang dapat dijadikan sebagai jaminan utang. Semakin kecil jumlah modal yang dimiliki perusahaan dapat menimbulkan dampak beban perusahaan kepada pihak kreditor semakin besar. Besarnya beban utang yang ditanggung oleh perusahaan dapat menurunkan jumlah laba yang diperoleh perusahaan. Hasil penelitian membuktikan bahwa debt to equity ratio berpengaruh negatif dan signifikan terhadap profitabilitas (Wikardi and Wiyani, 2017). Berdasarkan penjelasan tersebut maka hipotesis dalam penelitian ini.

H1 : Debt to equity ratio berpengaruh negatif terhadap profitabilitas

Current ratio mencerminkan kemampuan perusahaan dalam memenuhi kewajibannya ketika jatuh tempo. Semakin tinggi current ratio perusahaan berarti semakin besar kemampuan perusahaan untuk memenuhi kewajiban jangka pendek. Current ratio yang terlalu tinggi menunjukkan kelebihan aktiva lancar yang menganggur. Dalam teori likuiditas menjelaskan bahwa likuiditas yang jelek dalam jangka panjang juga akan mempengaruhi solvabilitas perusahaan Jadi hal tersebut tidak baik bagi profitabilitas perusahaan karena aktiva lancar menghasilkan return yang lebih rendah dibandingkan dengan aktiva tetap. Hasil penelitian (Sari and Dwirandra, 2019), serta (Supardi, H. Suratno and Suyanto, 2018) membuktikan bahwa current ratio berpengaruh negatif dan signifikan terhadap profitabilitas. Berdasarkan penjelasan tersebut maka hipotesis dalam penelitian ini.

H2: Current ratio berpengaruh negatif terhadap profitabilitas.

Firm Size menggambarkan besar kecilnya suatu perusahaan yang dapat dinyatakan dengan total aset. Firm Size merupakan salah satu faktor yang mampu mempengaruhi profitabilitas karena perusahaan berskala besar mempunyai lebih banyak kesempatan masuk ke dalam pasar modal yang dapat menarik para investor. Hal ini dikarenakan perusahaan berskala besar mempunyai fleksibilitas penempatan investasi yang lebih baik. Pada umumnya semakin besar perusahaan maka semakin besar pula aktivitasnya. Semakin besar ukuran perusahaan maka semakin besar aktivitas operasi perusahaan yang berarti semakin tinggi kemampuan perusahaan dalam menghasilkan profitabilitas. Teori critical resources juga mengindikasikan bahwa semakin besar skala perusahan maka profitabilitas juga akan meningkat, tapi pada titik atau jumlah tertentu ukuran perusahaan akhirnya akan menurunkan laba (profit) perusahaan. Hasil penelitian (Isık, 2017) menunjukkan bahwa firm size berpengaruh positif dan signifikan terhadap Profitabilitas. Berdasarkan argumen di atas dirumuskan hipotesis.

H3 = firm size berpengaruh positif terhadap profitabilitas

Penjualan merupakan bagian penting dalam aktivitas perusahaan. Salah satu sumber pendapatan perusahaan berasal dari penjualan. Jika perusahaan dapat mencapai sasaran penjualan yang tepat maka akan menambah pendapatan yang akan diperoleh perusahaan. Perusahaan juga harus mengelola penjualan dengan baik dan optimal karena jika dikelola dengan baik dan optimal maka akan berdampak kepada tingkat profit yang akan diperoleh perusahaan. Dalam teori sinyal juga dijelaskan bahwa pada waktu informasi diumumkan dan semua pelaku pasar sudah menerima informasi tersebut, pelaku pasar terlebih dahulu menginterpretasikan dan menganalisis informasi tersebut sebagai signal baik atau signal buruk dimana kondisi ini mampu mempengaruhi profitabilitas. Hasil penelitian yang dilakukan oleh (Setyawan and Susilowaty, 2018) membuktikan bahwa pertumbuhan penjualan berpengaruh positif dan signifikan terhadap profitabilitas. Dari uraian di atas hipotesis yang dapat dibuat.

$\mathrm{H} 4$ = pertumbuhan penjualan berpengaruh positif terhadap profitabilitas

Penelitian ini menggunakan paradigma kuantitatif. Untuk menguji hipotesis menggunakan analisis regresi linier berganda. Penelitian akan menguji Profitabilitas dengan menggunakan Return On Assets (Nursatyani, 2014), Debt to Equity Ratio (Maulita and Tania, 2018), Current Ratio (Sari and Dwirandra, 2019), Firm Size dengan menggunakan Ln Total Aset (Nurfadilah et al., 2015), dan Pertumbuhan Penjualan (Wikardi and Wiyani, 2017).

Penelitian ini menggunakan data penelitian sekunder. Populasi yang digunakan dalam penelitian ini adalah perusahaan manufaktur Sub Sektor Peralatan Rumah Tangga, kosmetik \& Keperluan Rumah Tangga dan Rokok yang terdaftar di Bursa Efek Indonesia periode tahun 2015 sampai dengan 2019 sebanyak 16 perusahaan. Dari populasi tersebut nantinya akan diambil sejumlah sampel untuk digunakan dalam penelitian.

Pemilihan objek penelitian dipilih dengan menggunakan teknik nonprobability sampling, dan metode yang digunakan purposive sampling method yaitu metode pemilihan sampel berdasarkan kriteria tertentu. Adapun kronologis pemilihan sampel dapat dilihat pada tabel 1 . 
Tabel 1. Kronologis Pemilihan Sampel

\begin{tabular}{|c|c|c|}
\hline No & Keterangan & Jumlah \\
\hline 1 & $\begin{array}{l}\text { Perusahaan manufaktur Sub Sektor } \\
\text { Peralatan Rumah Tangga, kosmetik \& } \\
\text { Keperluan Rumah Tangga dan Rokok } \\
\text { yang terdaftar di Bursa Efek Indonesia } \\
\text { (BEI) periode } 2015-2019 \text {. }\end{array}$ & 16 \\
\hline 2 & $\begin{array}{l}\text { Perusahaan tidak menerbitkan laporan } \\
\text { keuangan yang lengkap untuk periode } \\
\text { 2015-2019, telah mempublikasikan } \\
\text { laporan keuangannya di www.idx.co.id }\end{array}$ & (5) \\
\hline 3 & $\begin{array}{l}\text { Perusahaan tersebut yang menggunakan } \\
\text { mata uang rupiah, karena salah satu } \\
\text { variabel yang digunakan diukur dengan } \\
\text { menggunakan nilai nominal }\end{array}$ & $(0)$ \\
\hline & Jumlah Sampel & 11 \\
\hline
\end{tabular}

Metode analisis statistik yang digunakan dalam penelitian ini adalah metode regresi linier berganda. Analisis regresi linier berganda digunakan dalam penelitian ini karena variabel independen nya lebih dari satu. Bentuk persamaan dalam penelitian ini dinyatakan pada (5).

$$
\begin{aligned}
& \mathrm{Y}=\alpha+\beta_{1} \mathrm{X}_{1}+\beta_{2} \mathrm{X}_{2}+\beta_{3} \mathrm{X}_{3}+\beta_{4} \mathrm{X}_{4+} \mathrm{e} \\
& \text { Keterangan : } \\
& \mathrm{Y} \quad \text { : Return On Assets } \\
& \alpha \quad: \text { Konstanta } \\
& \beta_{1,2}: \text { Koefisien regresi masing-masing variabel } \\
& \mathrm{X}_{1} \quad \text { : Debt to Equity Ratio } \\
& \mathrm{X}_{2} \quad \text { : Current Ratio } \\
& \mathrm{X}_{3} \quad \text { : Firm Size } \\
& \mathrm{X}_{4} \quad \text { : Pertumbuhan Penjualan } \\
& \mathrm{e} \quad \text { : error }
\end{aligned}
$$

\section{PEMBAHASAN}

Hasil persamaan regresi pada penelitian dapat dilihat pada tabel 2 .

Tabel 2. Persamaan Regresi

\begin{tabular}{|c|c|c|c|c|c|}
\hline \multirow{2}{*}{ Model } & \multicolumn{2}{|c|}{$\begin{array}{c}\text { Unstandardized } \\
\text { Coefficients }\end{array}$} & $\begin{array}{c}\text { Standardized } \\
\text { Coefficients }\end{array}$ & & \\
\cline { 2 - 4 } & $\mathrm{B}$ & $\begin{array}{c}\text { Std. } \\
\text { Error }\end{array}$ & Beta & $\mathrm{t}$ & Sig. \\
\hline 1 (Constant) & -1.301 & .234 & & -5.564 & .000 \\
DER & .066 & .016 & .456 & 4.187 & .000 \\
CR & .020 & .008 & .268 & 2.390 & .021 \\
FS & .044 & .008 & .602 & 5.642 & .000 \\
PP & .126 & .148 & .090 & .852 & .398 \\
\hline
\end{tabular}

Sumber : Output SPSS (2019)

Persamaan regresi dalam penelitian ini pada (6).

$\mathrm{Y}=\beta+\mathrm{X} 1+\mathrm{X} 2+\mathrm{X} 3+\mathrm{X} 4+\mathrm{e}$

Profitabilitas $(\mathrm{ROA})=$

$-1.301+0.066 \mathrm{DER}+0.020 \mathrm{CR}+0.044 \mathrm{FS}+0.126 \mathrm{PP}+\mathrm{e}$

Keterangan :

Y : Profitabilitas (ROA)

$\mathrm{X} 1$ : Debt to Equity Ratio (DER)

$\mathrm{X} 2$ : Current Ratio (CR)

\begin{tabular}{|c|c|c|c|c|c|}
\hline Model & $\mathrm{R}$ & $\begin{array}{c}\mathrm{R} \\
\text { Square }\end{array}$ & $\begin{array}{c}\text { Adjuste } \\
\text { d R } \\
\text { Square }\end{array}$ & $\begin{array}{l}\text { Std. Error of } \\
\text { the Estimate }\end{array}$ & $\begin{array}{l}\text { Durbin- } \\
\text { Watson }\end{array}$ \\
\hline 1 & $.705^{\mathrm{a}}$ & .497 & .457 & .107118 & 1.883 \\
\hline
\end{tabular}

X3 : Firm Size (FS)
X4 : Pertumbuhan Penjualan (PP)

e : Error

Tabel 3 menunjukkan nilai koefisien determinasi dari model summary, dimana koefisien determinasi digunakan untuk menghitung besarnya peranan atau pengaruh variabel independen terhadap variabel dependen.

Tabel 3. Koefisien Determinasi

Sumber : Output SPSS (2019)

Berdasarkan tabel Model Summary tersebut dapat diketahui Koefisien Determinasi / KD / Adjusted $R$ Square menunjukkan 0,457 artinya sebesar $45.7 \%$ dari nilai Return On Assets ditentukan oleh variabel Debt to Equity Ratio, Current Ratio, Firm Size dan Pertumbuhan Penjualan. Sedangkan sisanya sebesar 54.3\% (100\% $45.7 \%$ ) dijelaskan oleh variabel-variabel lain diluar penelitian seperti misalnya Total Assets Turn Over, Assets Tangibility, Debt to Total Assets, Inventory Turnover.

Hasil pengolahan uji kelayakan model penelitian dapat dilihat pada tabel 4 .

Tabel 4. Tabel Uji Kelayakan Model

\begin{tabular}{|l|c|c|c|c|c|}
\hline \multicolumn{1}{|c|}{ Model } & $\begin{array}{c}\text { Sum of } \\
\text { Squares }\end{array}$ & df & $\begin{array}{c}\text { Mean } \\
\text { Square }\end{array}$ & F & Sig. \\
\hline Regressio & .567 & 4 & .142 & $\begin{array}{c}12.34 \\
7\end{array}$ & $\begin{array}{c}.000 \\
\mathrm{a}\end{array}$ \\
$\mathrm{n}$ & & & & & \\
Residual & .574 & 50 & .011 & & \\
Total & 1.140 & 54 & & & \\
\hline
\end{tabular}

a. Predictors: (Constant), PP, DER, FS, CR

b. Dependent Variable: ROA

Sumber : Output SPSS (2019)

Dari Uji kelayakan model pada tabel 4 diperoleh angka Sig. diketahui sebesar $0.000<0.05$, maka Ho5 ditolak Ha5 diterima. Hasil Uji $\mathrm{F}$ menunjukkan bahwa Ha diterima dan Ho ditolak, maka dapat disimpulkan bahwa model dalam penelitian ini layak untuk digunakan.

\subsection{Debt to Equity Ratio Terhadap Return On Assets}

Hasil pengujian hipotesis menunjukan bahwa Debt to Equity Ratio secara signifikan berpengaruh positif terhadap Return On Assets.

Hasil penelitian ini sesuai dengan Trade off Theory yang digunakan yaitu penggunaan hutang akan dapat meningkatkan nilai perusahaan sampai pada titik tertentu. Penggunaan hutang yang semakin meningkat 
akan menimbulkan kenaikan financial distress dan agency problem dimana hal ini dapat menyebabkan tingginya risiko kebangkrutan. Namun tidak selamanya hutang itu membawa dampak buruk bagi perusahaan, karena apabila hutang tersebut dikelola dengan baik, maka hal ini mampu menaikkan nilai perusahaan yang pada akhirnya mampu meningkatkan laba yang pada akhirnya tingkat pengembalian kepada investor juga akan meningkat.

Hasil peneliti ini konsisten dengan hasil penelitian yang dilakukan oleh (Wikardi and Wiyani, 2017), dan (Sari and Dwirandra, 2019) yang menunjukkan bahwa Debt to Equity Ratio berpengaruh signifikan terhadap Return On Asset. Tetapi tidak konsisten dengan hasil penelitian yang dilakukan oleh (Maulita and Tania, 2018) dan (Angelina et al., 2020) yang menunjukkan bahwa Debt to Equity Ratio tidak berpengaruh signifikan terhadap Return On Asset.

\subsection{Current Ratio Terhadap Return On Assets}

Hasil pengujian hipotesis menunjukkan bahwa Current Ratio secara signifikan berpengaruh positif terhadap Return On Assets.

Hasil penelitian ini sesuai dengan Teori Likuiditas yang menyatakan kemampuan suatu perusahaan dalam memenuhi kewajiban jangka pendeknya. Adanya pengaruh yang signifikan dari $\mathrm{CR}$ terhadap ROA mengandung arti bahwa CR yang besar pada perusahaan di interpretasikan bahwa perusahaan memiliki lebih banyak sumber-sumber aset yang dapat dikonversi menjadi kas yang berasal dari laba perusahaan. Komponen aktiva lancar yang dapat dikonversi menjadi kas adalah persediaan (inventory) dan piutang dagang yang dapat menjadi sumber pendapatan bagi perusahaan. Hasil ini mengindikasikan pula bahwa perusahaan dapat memaksimalkan keuntungannya dengan cara mengelola dengan sebaik-baiknya atas aktiva lancar mereka yang berasal dari kas, pengumpulan piutangnya dan persediaan. Perusahaan dapat manfaat berupa masuknya kas ke dalam perusahaan lewat pelunasan piutang sehingga akan meningkatkan pendapatan perusahaan. Peningkatan pendapatan ini akan mendukung kegiatan operasi perusahaan nantinya sehingga dapat menghasilkan keuntungan yang besar bagi perusahaan. Dengan kata lain kondisi aktiva lancar yang semakin baik memberikan sinyal positif bagi perusahaan dalam menjalankan aktivitas operasionalnya sehingga akan mendapatkan keuntungan yang lebih besar.

Hasil penelitian ini konsisten dengan hasil penelitian yang dilakukan oleh (Nursatyani, 2014), (Isık, 2017), (Sari and Dwirandra, 2019), dan (Angelina et al., 2020) yang menunjukkan bahwa Current Ratio berpengaruh signifikan terhadap Return On Asset. Tetapi tidak konsisten dengan hasil penelitian yang dilakukan oleh (Warrad, 2015), dan (Supardi, H. Suratno and Suyanto, 2018) yang menunjukkan bahwa Current Ratio berpengaruh signifikan terhadap Return On Asset.

\subsection{Firm Size Terhadap Return On Assets}

Hasil pengujian hipotesis menunjukkan bahwa Firm Size secara signifikan berpengaruh positif terhadap Return On Assets.

Hasil penelitian ini sesuai dengan Teori Critical Resource yang menekankan pada pengendalian oleh pemilik perusahaan terhadap sumber daya perusahaan seperti asset, technology, intellectual property sebagai faktor-faktor yang menentukan firm size (skala perusahaan). Teori ini menghubungkan ukuran perusahaan dengan kemampuan entrepreneur (pemilik usaha) dalam mengendalikan "intangible factors" yang dapat mendorong perusahaan lebih profitable. Teori critical resources juga mengindikasikan bahwa semakin besar skala perusahan maka profitabilitas juga akan meningkat. Firm Size juga merupakan salah satu faktor yang mampu mempengaruhi profitabilitas karena perusahaan berskala besar mempunyai lebih banyak kesempatan masuk ke dalam pasar modal yang dapat menarik para investor. Hal ini dikarenakan perusahaan berskala besar mempunyai fleksibilitas penempatan investasi yang lebih baik. Pada umumnya semakin besar perusahaan maka semakin besar pula aktivitasnya. Semakin besar ukuran perusahaan maka semakin besar aktivitas operasi perusahaan yang berarti semakin tinggi kemampuan perusahaan dalam menghasilkan profitabilitas.

Hasil peneliti ini konsisten dengan hasil penelitian yang dilakukan oleh (Wikardi and Wiyani, 2017) dan (Isık, 2017) yang menunjukkan bahwa Firm Size berpengaruh signifikan terhadap Return On Asset. Tetapi tidak konsisten dengan hasil penelitian yang dilakukan oleh (Nursatyani, 2014) yang menunjukkan bahwa Firm Size tidak berpengaruh signifikan terhadap Return On Asset.

\subsection{Pertumbuhan Penjualan Terhadap Return On Assets}

Hasil pengujian hipotesis menunjukkan bahwa Pertumbuhan Penjualan tidak berpengaruh terhadap Return On Assets.

Hasil penelitian ini tidak sesuai dengan Teori Sinyal dimana tingkat pertumbuhan penjualan yang terus meningkat belum tentu diikuti dengan profitabilitas yang terus meningkat juga. Tidak berpengaruhnya pertumbuhan penjualan terhadap profitabilitas dikarenakan pertumbuhan penjualan bukan merupakan faktor utama yang dapat memengaruhi profitabilitas, karena pertumbuhan penjualan disertai dengan peningkatan biaya dan penambahan aktiva yang lebih besar, sehingga peningkatan profitabilitas yang diharapkan tidak tercapai. Penjualan harus dapat menutupi biaya sehinga dapat meningkatkan keuntungan. Namun yang terjadi pada perusahaan manufaktur sub sektor peralatan rumah tangga, kosmetik \& keperluan rumah tangga dan rokok yang terdaftar di Bursa Efek Indonesia tahun 2015-2019 ini pertumbuhan penjualannya disertai juga dengan penambahan asset dan 
biaya sehingga peningkatan profitabilitas yang diharapkan tidak tercapai.

Hasil peneliti ini konsisten dengan hasil penelitian yang dilakukan oleh (Mappanyuki and Sari, 2017) yang menunjukkan bahwa Pertumbuhan Penjualan tidak berpengaruh signifikan terhadap Return On Asset. Tetapi tidak konsisten dengan hasil penelitian yang dilakukan oleh (Setyawan and Susilowaty, 2018) yang menunjukkan bahwa Pertumbuhan Penjualan berpengaruh signifikan terhadap Return On Asset.

\section{KESIMPULAN}

Hasil penelitian ini menunjukkan bahwa debt to equity ratio, current ratio, dan firm size berpengaruh positif dan signifikan terhadap profitabilitas, sedangkan pertumbuhan penjualan tidak berpengaruh terhadap profitabilitas. Nilai profitabilitas yang diproksikan dengan Return On Assets ditentukan oleh variabel Debt to Equity Ratio, Current Ratio, Firm Size dan Pertumbuhan Penjualan sebesar 45.7\%, sisanya dijelaskan oleh variabel-variabel lain diluar penelitian seperti Total Assets Turn Over, Assets Tangibility, Debt to Total Assets, Inventory Turnover.

\section{SARAN}

Berdasarkan hasil kesimpulan, saran yang dapat diberikan penulis adalah peneliti selanjutnya dapat menambah variabel dan memperluas populasi penelitian tidak terbatas dalam Perusahaan Manufaktur Sub Sektor Peralatan Rumah Tangga, kosmetik \& Keperluan Rumah Tangga dan Rokok yang terdaftar di Bursa Efek Indonesia Tahun 2015-2019.

Saran bagi perusahaan adalah hutang harus dikelola dengan baik sehingga perusahaan mampu memenuhi kewajiban-kewajibannya dan tidak mengalami kesulitan keuangan, meningkatkan kinerja perusahaan, salah satunya dapat kita cerminkan dari semakin besarnya nilai Current Ratio yang dapat mempengaruhi profit yang perusahaan dapatkan agar dapat menarik perhatian investor asing maupun investor dalam negeri untuk menanamkan saham mereka pada perusahaan, perusahaan menekankan pada pengendalian oleh pemilik perusahaan terhadap sumber daya perusahaan seperti asset, technology, intellectual property sebagai faktorfaktor yang menentukan firm size (skala perusahaan) karena kemampuan entrepreneur (pemilik usaha) dalam mengendalikan "intangible factors" dapat mendorong perusahaan lebih profitable, perusahaan juga harus memperhatikan laju pertumbuhan penjualan serta mampu menekan dan melakukan efisiensi terhadap biaya-biaya yang dikeluarkan karena pertumbuhan penjualan disertai dengan peningkatan biaya dan penambahan aktiva yang lebih besar, maka tingkat laba yang diharapkan tidak dapat tercapai secara maksimal.

\section{DAFTAR PUSTAKA}

Angelina, C. et al. 2020. 'Pengaruh Current Ratio, Debt to Equity, Perputaran Kas dan Total Asset Turn Over (TATO) Terhadap Profitabilitas pada Perusahaan Food \& Beverages yang terdaftar di Bursa Efek Indonesia', Owner, 4(1), p. 16. doi: 10.33395/owner.v4i1.178.

Efendi, A., Putri, L. P. and Dungga, S. 2019. 'The Effect of Debt to Equity Ratio and Total Asset Turnover on Return on Equity in Automotive Companies and Components in Indonesia', (September). doi: 10.2991/icame-18.2019.20

Isik, O., Unal, E. A., \& Unal, Y. 2017. The effect of firm size on profitability: evidence from Turkish manufacturing sector. Journal of Business Economics and Finance, 6(4), 301-308.

Mappanyuki, R. and Sari, M. 2017. 'The effect of sales growth ratio, inventory turnover ratio, growth opportunity to company's profitability (survey in Indonesia's stocks exchange)', International Journal of Management and Applied Science, 3(3), pp. 139147. Available www.worldresearchlibrary.org/up proc/pdf/646148757128008-16.pdf.

Maulita, D. and Tania, I. 2018. 'Pengaruh Debt To Equity Ratio (Der), Debt To Asset Ratio (Dar), Dan Long Term Debt To Equity Ratio (Lder) Terhadap Profitabilitas', Jurnal Akuntansi: Kajian Ilmiah Akuntansi (JAK), 5(2), p. 132. doi: 10.30656/jak.v5i2.669.

Nurfadilah et al. 2015. 'Pengaruh Leverage, Ukuran Perusahaan, dan Kualitas Audit Terhadap Penghindaran Pajak ( Studi Empiris pada Perusahaan Manufaktur yang terdaftar di Bursa Efek Indonesia Tahun 2011-2015 )', Seminar Nasional dan The 3rd Call for Syariah Paper, (2010), pp. 441-449.

Nursatyani, A. 2014. 'Analisis Pengaruh Current Ratio, Firm Size, dan Assets Tangibility Terhadap Return On Asset dengan Debt To Total Asset Sebagai Variabel Intervening (Studi pada Perusahaan Sektor Pertambangan yang Terdaftar di BEI Tahun 20082011)', Jurnal Bisnis Strategi, 23(2), pp. 97-127. doi: 10.14710/jbs.23.2.97-127.

Sari, P. R. P. and Dwirandra, A. A. N. B. 2019. 'Pengaruh Current Ratio Dan Debt To Equity Ratio Terhadap Profitabilitas Dengan Intellectual Capital Sebagai Pemoderasi', E-Jurnal Akuntansi, 26, p. 851. doi: 10.24843/eja.2019.v26.i02.p01.

Setyawan, S. and Susilowaty, S. 2018. 'Analisis Pertumbuhan Penjualan Dan Perputaran Modal Kerja Terhadap Profitabilitas PT. Tiga Pilar Sejahtera Food, Tbk Tahun 2012-2016', Akuntabilitas, 11(1), pp. 147-158. doi: 10.15408/akt.v11i1.7180.

Supardi, H., H. Suratno, H. S. and Suyanto, S. 2018. 'Pengaruh Current Ratio, Debt To Asset Ratio, Total Asset Turnover Dan Inflasi Terhadap Return on Asset', JIAFE (Jurnal Ilmiah Akuntansi Fakultas Ekonomi), 2(2), pp. 16-27. doi: 10.34204/jiafe.v2i2.541.

Warrad, L. 2015. 'The Effect of Current Ratio on 
Jordanian Real Estate Sector 's Net Profit Margin The Effect of Current Ratio on Jordanian Real Estate Sector' s Net Profit Margin', European Journal of Economics, Finance and Administrative Sciences, 63(2), pp. 34-39.

Wikardi, L. and Wiyani, N. 2017. 'Pengaruh Debt To Equity Ratio, Firm Size, Inventory Turnover, Assets Turnover dan Pertumbuhan Penjualan terhadap Profitabilitas (Studi Kasus pada Industri Makanan dan Minuman yang Terdaftar di BEI Periode 20112015)', Jurnal Online Insan Akuntan, 2(1), p. 234099 .

\section{UCAPAN TERIMA KASIH}

Terima kasih kepada Yayasan Pendidikan Budi Luhur Cakti yang telah mendanai penelitian ini sampai selesai. 